\title{
Rumah Tangga Gembala Sidang Menjadi Role Model Bagi Jemaat
}

\section{Lena Anjarsari Sembiring}

Program Studi Magister Pendidikan Agama Kristen Universitas Kristen Indonesia

Email: lenaanjarsari27@gmail.com

\section{Simon}

Sekolah Tinggi Teologi Salatiga

Email: simonpetrus45144@gmail.com

\begin{abstract}
This paper discusses the congregation pastor household being a role model for the congregation. The method used in this research is descriptive qualitative method with a literature approach.

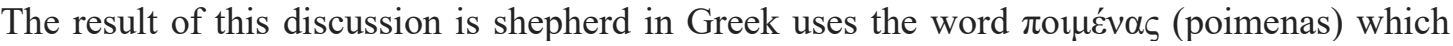
means a feeder, protector and guide. God gives a pastor's ministry to a person for the purpose of carrying out the task of shepherding and educating His people so that they can live more properly and spiritually mature. Through the task God has delegated to the pastor to serve the congregation, his life and household should become a role model for the congregation. The pastor becomes a role model for the congregation starting from his marriage, has a good track record in life, is able to lead all members of his family, and the wife's lifestyle does not become a stumbling block. Why is the congregation pastor's household required to be a role model for the congregation, because the congregation pastor is closely related to the spiritual arrangement and arrangement of the church's household life.
\end{abstract}

Keywords: Pastor, Household, Congregation

\begin{abstract}
Abstrak
Tulisan ini membahas mengenai Rumah Tangga Gembala Sidang Menjadi Role Model Bagi Jemaat. Metode yang digunakan dalam penelitian ini adalah metode kualitatif dengan pendekatan kepustakaan. Hasil dari pembahasan ini adalah gembala dalam bahasa Yunani

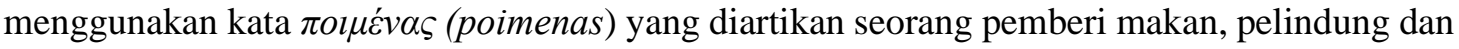
penuntun. Tuhan mengaruniakan jawatan gembala kepada seseorang tujuannya untuk mengemban tugas menggembalakan dan mendidik jemaat-Nya agar mereka makin hidup benar dan dewasa secara kerohanian. Melalui tugas yang didelegasikan oleh Allah kepada gembala sidang untuk melayani jemaat, maka kehidupan dan rumah tangganyapun sudah sepatutnya menjadi role model bagi jemaat. Gembala sidang menjadi role model bagi jemaat dimulai dari pernikahannya, memiliki track record hidup yang baik, mampu memimpin seluruh anggota keluarganya, serta gaya hidup istri tidak menjadi batu sandungan. Mengapa rumah tangga gembala sidang dituntut menjadi role model bagi jemaat, karena gembala sidang erat kaitannya dalam penataan kerohanian dan penataan kehidupan rumah tangga jemaat.
\end{abstract}

Kata kunci: Gembala Sidang, Rumah Tangga, Jemaat

\section{Pendahuluan}

Fakta mengungkapkan bahwa ada sebagian gembala sidang kondisi rumah tangganya tidak menjadi role model (panutan) bagi rumah tangga jemaat yang digembalakannya. Rumah tangganya tidak menjadi percontohan bagi jemaat malahan menjadi pergunjingan karena tidak menjadi contoh. Adapun contohnya hamba Tuhan yang bernama DH yang berasal dari 
Surabaya, ia menceraikan suaminya demi menikahi jemaat yang digembalakannya (Wahyudiyanta, 2016). Ada juga hamba Tuhan yang berinisal HL, tega mencabuli jemaatnya seorang pemudi remaja yang sudah tahunan diperbuatnya (Ariefana, 2020). Contoh lain adanya pendeta yang berseteru dengan anaknya hanya karena warisan pelayanan, hingga menyebabkan pertikaian dalam penggembalaan.

Kasus-kasus yang dialami oleh pendeta di atas menunjukkan, bahwa sebagian gembala sidang keadaan rumah tangganya tidak menjadi role model bagi jemaat sehingga berdampak pada "kecacatan" dalam pelayanan penggembalaan. Padahal gembala merupakan salah satu jawatan ke-pelayanan yang diberikan Allah kepada seseorang dengan tujuan untuk mendidik dan merawat jemaat agar bertumbuh dalam pengenalan kepada Allah. Sebagaimana yang dikemukakan Telaumbanua gembala sidang memiliki peran yang sangat penting dalam pertumbuhan rohani jemaat Tuhan. Peran seorang gembala sidang dalam hal ini yang paling utama adalah melayani jemaat. Seorang gembala menerima perintah dari surga dan harus melakukannya, apapun yang akan terjadi, karena pada akhirnya dia akan mempertanggungjawabkannya kepada Allah (Telaumbanua, 2019).

Seorang gembala dirinya tidak hanya dituntut untuk melakukan tugas ke-pastoralannya dengan rajin visitasi jemaat, memiliki kapasitas dalam kepemimpinannya, cakap mengajar dan berkotbah. Tidak hanya seputar itu saja yang harus diperhatikan oleh gembala sidang, akan tetapi keteladanan hidup serta rumah tangganya dicontoh merupakan hal yang penting ditiru oleh jemaat. Apalah artinya gembala sidang terampil dan berkapasitas dalam pelayanan, tetapi pribadinya dan rumah tangganya tidak menjadi role model bagi jemaat yang digembalakan. Sejatinya dikehidupan nyata, pendeta dan keluarganya haruslah bersikap penuh bijaksana ketika menampilkan gaya hidup di hadapan jemaat. Jadilah teladan contoh bagi jemaat dalam menampilkan cara hidup yang sederhana tanpa bersikap pamer sekalipun mampu secara ekonomi (Simon, 2019). Pendapat senada dikemukakan oleh Riggs bahwa seorang hamba Tuhan itu harus memiliki kehidupan yang benar, diterima oleh masyarakat gereja, ini adalah sebuah integritas diri yang sangat penting dalam menunjang diri sebagai hamba Tuhan (Riggs, 1996).

Ada ungkapan bijak berkata "contoh yang baik untuk mengajar jemaat adalah pribadi hamba Tuhan serta keadaan rumah tangganya menjadi role model untuk menjadi panutan kepada jemaat. Rasul Paulus pun menyatakan kepada jemaat di Filipi yang dirintisnya, untuk mengikuti teladannya (Fil. 3:17). Ungkapan rasul Paulus yang menyatakan agar jemaat mengikuti keteladanan akan hidupnya, menjadi hal yang mendasariah agar jemaat Filipi menjadikan pribadi Paulus sebagai role model mengenai karakter dan keimanannya. Demikian juga halnya gembala sidang, agar hidup dan rumah tangganya menjadi role model bagi jemaat. Sihombing menyatakan keluarga hamba Tuhan menjadi satu praktek percontohan karakteristik dalam pelayanan, karena melalui pengalaman-pengalaman yang ia alami dapat menjadi satu pelajaran untuk mengetahui langsung bagaimana kehidupan keluarga. Melalui kehidupan hamba Tuhan dan keluarganya, ia dapat secara tidak langsung memberikan contoh kepada 
jemaat dan lingkungan bagaimana sesungguhnya kehidupan keluarga hamba Tuhan yang baik dan harmonis dan yang berkenan kepada Allah, (Sihombing, 2014).

Rumah tangga gembala sidang merupakan hal yang sering disorot dan diperhatikan oleh jemaat. Jika jemaat melihat rumah tangga gembalanya tidak menjadi role model atau panutan, maka akan tercipta gap antara jemaat dan gembala sidang. Jemaat akan berpikir, bagaimana mungkin keluarganya dapat dituntun berohani, sementara rumah tangga si gembala sidang tidak menjadi role model sebagaimana yang diajarkan oleh si gembala. Wongso mengemukakan seorang pendeta merupakan pemimpin bagi jemaat, karena ia pemimpin maka sikap dan perbuatan sering kali diteladani oleh jemaat. Oleh sebab itu, para pemimpin harus memelihara sikap dan perbuatan jemaatnya dengan sebaik-baiknya, yang terpenting adalah pemimpin harus mampu memberi teladan bagi orang lain (Wongso, 1983). Kenyataannya ada saja keluarga yang tidak harmonis, dikarenakan beberapa hal, adanya perceraian, masing-masing terlalu sibuk bekerja, (pelayanan) akibatnya tidak tercipta kebersamaan antara suami, istri dan anak, serta tidak terpenuhi spiritualitas secara merata dalam keluarga (Aqsho, 2017).

Permasalahan dalam kajian ini, yaitu bagaimana role model rumah tangga gembala sidang yang didasarkan pada kebenaran firman Tuhan untuk menjadi panutan bagi jemaat? Adapun tujuan dari tulisan ini terdiri dua hal, yaitu secara teoritis dan praksis. Secara teoritis, tulisan ini menguraikan tentang role model rumah tangga berdasarkan prinsip kebearan firman Allah. Sementara praksisnya, uraian ini menjadi sebuah petunjuk buat gembala sidang tentang rumah tangga yang menjadi role model bagi jemaat yang teraplikasikan dalam pelayanan kepastoralan.

\section{Metodologi Penelitian}

Menurut Mulyana (2002), metode adalah proses, prinsip dan prosedur yang digunakan untuk suatu pendekatan dalam mengkaji topik penelitian hingga mencari jawaban. Sedangkan menurut Sugiyono (2014) menyatakan bahwa penelitian itu cara ilmiah untuk mendapatkan data dengan tujuan dan kegunaan tertentu. Berdasarkan pengertian tersebut terdapat empat yang perlu perlu dipahami lebih lanjut yaitu: cara ilmiah, data, tujuan dan kegunaan. Penelitian merupakan cara ilmiah, berarti penelitian itu didasarkan pada ciri keilmuannya seperti rasional, empiris dan sistematis (Sugiyono, 2014). Tulisan ini menggunakan metode kualitatif dengan pendekatan kepustakaan. Pendekataan kepustakaan dipilih untuk memperoleh data-data primer baik dari buku maupun dari jurnal. Zed (2008) mengemukakan pendekataan kepustakaan untuk menjawab pertanyaan penelitian, sebab penelitian tersebut hanya dapat dijawab melalui penelitian kepustakaan karena data penelitian yang diperoleh berasal dari sumber perpustakaan. Di samping itu data faktual di lapangan akan dikemukakan untuk menambah keabsahan pointpoint tentang rumah tangga gembala sidang yang menjadi role model bagi jemaat. Data faktual itu diperoleh oleh peneliti dengan mewawancarai gembala-gembala sidang. Prosedural bentuk wawancaranya yang dilakukan kepada gembala sidang melalui WhatsApp dan Telephone. 


\section{Hasil Dan Pembahasan \\ Tentang Gembala Sidang}

Gembala merupakan salah satu jawatan yang ditulis oleh Alkitab dari lima jawatan dalam gereja. Sebagaimana yang ditulis oleh Alkitab "Dan Ialah yang memberikan baik rasulrasul maupun nabi-nabi, baik pemberita-pemberita Injil maupun gembala-gembala dan pengajar-pengajar, untuk memperlengkapi orang-orang kudus bagi pekerjaan pelayanan, bagi pembangunan tubuh Kristus (Ef. 4:11-12). Gembala dalam bahasa Yunani menggunakan kata $\pi o u$ ćvas (poimenas) yang diartikan seorang pemberi makan, pelindung dan penuntun. Tetapi oleh Masweli sebutan gembala di masa kini adalah seseorang yang memimpin jemaat, mengarahkan kerohaniannya. Karena itu gembala sidang merupakan orang yang istimewa, jika ia dikaruniakan dan terpanggil untuk pelayanan ini, berarti Allah telah menyuruh dia untuk memelihara umat-Nya, (Crider \& Donald, 2002). Yesus disebut sebagai Gembala Yang Agung (1 Ptr. 5:4), karena memang Dialah pemelihara dan penuntun setiap kehidupan umat-Nya. Ia sebagai Gembala Agung karena Ia memberikan nyawanya bagi umat-Nya (Yoh. 10:11). Tentang hal ini Sumiwi mengemukakan dalam Yohanes 10:11 Tuhan Yesus menyebut diri-Nya "gembala yang baik." Ada kebenaran doktrinal yang terkait dengan gelar ini. Ketika dikatakan, "Gembala yang baik" memberikan nyawanya bagi domba-dombanya," tidak ada keraguan bahwa kematian Tuhan Yesus terkait dengan gelar ini. Kebenaran-kebenaran tertentu dapat diperoleh dari pasal tentang kematian-Nya. Itu adalah kematian sukarela (Yoh. 10:17, 18) (Sumiwi, 4 C.E., p. 85). Senada dengan apa yang dikemuakan oleh Barcley (2000) bahwa Yesus adalah gembala yang baik. Dia adalah gembala yang bersedia mengorbankan hidup-Nya untuk manusia yang tersesat dalam dosa.

Semenjak berlalunya era ke-rasulan, gembala sidang merupakan salah satu jawatan dalam panggilan yang berperan signifikan dalam penyebaran Injil dan pengajaran firman Allah di masa kini. Signifikannya peran gembala sidang akan hal ini, karena memang tidak terlepas bagaimana pesan Tuhan kepada Petrus untuk menggembalakan domba-domba-Nya (Yoh. 21;19). Ungkapan Yesus menyatakan "gembalakanlah domba-dombaku" dapat dimaknai secara sederhana bahwa tongkat estafet dalam pemberitaan Injil dan mengajari orang-orang percaya mengenai firman Allah ada dalam pundak seorang gembala sidang yang dipercayakan Tuhan. Borrong mengemukakan pekerjaan sebagai pendeta merupakan kelanjutan dari pekerjaan orang-orang terpanggil secara khusus menjadi wakil dan mitra Allah dalam memberitakan firman-Nya di dunia ini. Karena itu pendeta adalah orang-orang terpanggil seperti imam, nabi, raja, dan rasul, khususnya gembala, untuk menjalankan tugas dan fungsi selaku pemberita kehendak dan maksud Tuhan kepada umat manusia di dunia ini (Borrong, 2015). Oleh sebab itu segmen pelayanan gembala sidang di masa kini memberitakan Injil, mengajar dan memuridkan orang percaya untuk menjadi penuai bagi Kristus. Kosta mengemukakan dalam 1 Petrus 5:2 menggambarkan tugas seorang gembala dengan kiasan yang baik, di mana mereka dipercayakan untuk menggembalakan domba Allah yaitu memberi makan. Kata ini mengingatkan amanat Tuhan Yesus kepada Petrus dalam Yohanes 21:15-19. Ungkapan "yang 
ada padamu" adalah ungkapan istimewa dalam bahasa Yunani dengan seluruh kemampuanmu, sekuat tenaga (Kosta, 2011).

Akan tetapi sayangnya di masa kini sebagian gembala sidang tidak menyadari fungsi tugas ke-gembalaannya tidak dioptimalkan dengan maksimal. Kecenderungan gembala sidang sebagian di masa kini hanya berfokus mengurusi bagian administrasi ke-gerejawi-an. Padahal Alkitab sudah merincikan bahwa gembala sidang itu segmen pelayanan utamanya adalah mendidik jemaat-jemaat dalam pengajaran firman Allah. Gembala sidang memiliki peran yang sangat penting dalam pertumbuhan rohani jemaat Tuhan. Adapun peran paling utama adalah melayani jemaat. Mengapa, karena seorang gembala menerima mandat itu dari surga dan harus melakukannya, karena pada akhirnya dia akan mempertanggung-jawabkannya kepada Allah. Apabila ia telah menerima pendelegasian tugas kegembalaanya, maka sebaiknya seorang gembala harus melayani Allah dengan sungguh-sungguh, bertanggung jawab serta aktif mengawasi kehidupan jemaat khususnya kualitas kerohaniannya (Telaumbanua, 2019). Dengan jawatan panggilan sebagai gembala bagian dari meneruskan warisan apa yang pernah diperbuat oleh para rasul-rasul dahulu kala dengan mendidik, menobatkan, dan memelihara para jemaatjemaat baru yang terbentuk yang nantinya menjadi gereja lokal.

\section{Rumah Tangga Gembala Menjadi Role Model Bagi Jemaat Pernikahan Yang Tidak Bercacat Cela}

Pernikahan merupakan wadah yang didesain Allah agar umat manusia dapat menyalurkan hasrat seksualitasnya dalam hubungan intim yang legal atau sah di mata Tuhan dan dihadapan khalayak umum. Tanusaputra menyatakan seksualitas itu rangkaian perasaanperasaan dan tindakan yang dimiliki dan digunakan manusia dalam wujud pribadi yang diciptakan laki-laki dan perempuan. Seksualitas merupakan hubungan yang diekspresikan bagi diri kita sendiri dan orang lain melalui pandangan, sentuhan dan tindakan (Tanusaputra, 2005). Karena itu pernikahan adalah lembaga manusiawi yang diakui dan diatur dangan undangundang disemua masyarakat. Namun, lembaga perkawinan itu bukanlah ciptaan manusia. Ajaran Kristen tentang topik perkawinan dimulai dengan penegasan yang penuh kegembiraan bahwa perkawinan merupakan gagasan Allah, bukan gagasan kita (Stott, 2015). Sementara menurut Sabdono (2018) mengemukakan bahwa Allahlah yang menentukan sejak semula bahwa laki-laki harus dipersatukan dengan perempuan. Pernikahan sama sekali bukan prakarsa manusia, tetapi prakarsa Allah sendiri. Karena itu, pernikahan harus diakui dan diterima sebagai suatu karunia atau anugerah Allah atas manusia. Oleh karena itu tujuan dari pernikahan selain reproduksi manusia, pembentukan keluarga yang harmonis untuk menciptakan keluarga yang benar di mata Allah merupakan bagian dari pernikahan itu sendiri. Dengan terbentuknya keluarga melalui sebuah pernikahan, maka berkat sorgawi dihadirkan dalam rumah tangga itu.(Simon, 2020b) Gembala sidang menjadi role model bagi jemaat dimulai dari pernikahannya tidak bercacat cela atau sederhananya tidak ber-aib. 
Pernikahan tidak bercacat cela yang dimaksud ialah mampu menjaga orisinalitas keperjakaannya bila ia pria, begitu juga dengan wanita ia menjaga ke-perawanannya. Dalam perspektif umum dan Alkitab pernikahan itu tidak bercacat cela dimulai dari tidak melakukan persetubuhan sebelum ia masuk dalam gerbang pernikahan. Rumah tangga gembala sidang menjadi role model bagi jemaat dimulai dengan tidak adanya kecacat-celaan pernikahan mereka sebagai suami istri. Hamba Tuhan yang telah mengabdikan diri, dan berbakti kepada Tuhan diperintahkan supaya hidup kudus dengan melepaskan diri dari perbuatan kotor atau dosa. (Pardede, 2019).

Mengapa pernikahan gembala sidang dituntut harus menjadi role model bagi jemaat, karena gembala erat kaitannya dengan tugasnya sebagai orang yang melakukan prosesi "pemberkataan" pernikahan kepada jemaat. Jika gembala sidang melaksanakan tugas kegembalaanya dengan mandat dari Tuhan untuk "mensahkan" calon suami istri menjadi pasangan yang sah melalui prosesi pemberkatan nikah, tetapi latar belakang pernikahan gembala sidang ada kecacatan cela, bukankah hati nuraninya akan menuduh ia sebagai pembohong? Itulah sebabnya rumah tangga gembala sidang menjadi role model bagi jemaat indikatornya dimulai dari pernikahan si gembala tersebut. Alkitab menulis "karena seorang gembala jemaat haruslah orang yang baik, yang hidupnya tidak bercacat cela. Ia harus beristrikan satu saja, harus rajin dan bijaksana, tertib serta senantiasa berbuat baik. Ia harus senang menerima tamu di rumahnya, dan ia haruslah seorang guru Alkitab yang cakap" (1 Tim. 3:2 Terjemahan FAYH). Arifianto (2020b) mengemukakan hamba Tuhan yang memiliki integritas yang dapat disebut orang yang dianggap baik, dapat menjadi panutan, dapat dipercaya, orang yang setia, jujur, serta jauh dari kepalsuan dan kepura-puraan.

Jawatan gembala yang diberikan Tuhan bagi seseorang bukanlah amanah yang mudah di emban, karena seorang gembala yang dipilih oleh Allah harus mampu menselaraskan dirinya dan pernikahannya sesuai dengan kriteria Allah sendiri. Pada zaman PL, mereka yang dipilih sebagai imam yang bertugas di Bait Allah sebagai perantara bagi umat Israel, Allah menuntut kriteria para imam itu hidup kudus. Hidup kudus dapat dimaknai tidak ada kekurangan fisik serta ia tidak melakukan perbuatan-perbuatan yang tercela. Bila diimplementasikan di masa kini, gembala adalah pilihan khusus sendiri dari Tuhan kepada seseorang untuk menggembalakan jemaat. Karena panggilan gembala merupakan pemberian Allah secara pribadi kepada seseorang, maka penting baginya menjaga agar tidak melakukan perbuatanperbuatan tercela sehingga label pernikahannya yang kudus itu terjaga. Fakta di lapangan yang penulis lihat berdasarkan pengakuan responden RS yang peneliti wawancarai, ia mengungkapkan ada individu-individu gembala sidang pernikahannya tidak menjadi role model bagi jemaat. Sebab, sebelum melangsungkan pernikahan, oknum tersebut sudah terlebih dahulu melakukan persetubuhan dengan calon istrinya. Apabila sudah melakukan persetubuhan sebelum resmi menjadi suami istri, bukankan pernikahannya itu sudah ber-aib dalam pandangan umum. 


\section{Memiliki Latar Belakang Kehidupan Yang Baik}

Gembala sidang yang memiliki track record hidup yang baik juga merupakan role model yang baik bagi jemaat. Yang dimaksud dengan track record yang baik masa muda si gembala tidak pernah terlibat dalam penggunaan narkoba, tidak pernah masuk penjara karena melakukan tindakan kriminal, serta tidak menjadi mantan pecandu miras dan rokok. Alkitab menulis agar menjaga kelakuan di tengah-tengah orang yang belum diselamatkan. Meskipun waktu itu mereka mencurigai serta menentang saudara, kelak pada waktu Kristus kembali, mereka akan memuji Allah. Dengan memelihara perilaku yang baik, orang lain tidak ada celah menfitnah (1 Ptr. 2:12-13 Terjemahan FAYH). Gembala perlu memiliki track record hidup yang baik karena pendeta itu bagian dari keprofesian yang selalu bersentuhan dengan penilaian moral di khalayak umum. Borrong (2015) mengemukakan pekerjaan sebagai pendeta bersentuhan secara langsung dengan penilaian yang bersifat moral, baik dari jemaat maupun dari publik. Itu sebabnya pekerjaan pendeta justru membutuhkan kode etik. Tidak sedikit pendeta yang jatuh karena dianggap melanggar atau melintas batas norma-norma moral (Borrong, 2015). Jika gembala sidang memiliki track record hidup yang buruk di masa lampau tentu dapat mempengaruhi jemaat untuk tidak menjadikan dirinnya sebagai role model.

Walau tidak menjadi penentu kehidupan masa lalu seorang gembala sidang untuk menjadi role model bagi jemaat, namun sebagai gembala yang dipilih Allah secara khusus, apabila ia memiliki track record yang baik secara moral dalam tatanan masyarakat, tentu hal itu menjadi nilai plus bagi jemaat agar tidak perlu meragukan kehidupan sigembala sebagai orang yang layak diteladani. Keuntungan gembala sidang memiliki track record yang baik sebelum ia menjadi seorang gembala, mencegah jemaat bersikap sinis apabila ia mengenalinya semenjak diusia masa mudanya. Bila gembala track recordnya hidupnya menjadi percontohan bagi jemaat, tentu itu menjadi kesaksian bagi jemaat. Karena kepribadian gembala sebagai pemimpin gereja merupakan salah satu penentu dari perkembangan gereja yang dipimpinnya. Mau tidak mau, seorang pemimpin gereja harus memiliki, menjaga dan meningkatkan kredibilitas pribadinya dari waktu ke waktu. Kredibilitas pribadi seorang pemimpin seharusnya akan memberi nilai tinggi bagi setiap pemimpin dimata mereka yang dipimpin dan mereka yang ada disekitar kelompok yang dipimpinnya. Kredibilitas pribadi seorang gembala yang mumpuni seharusnya akan mampu mengembangkan organisasi gereja yang dipimpinnya (Rajagukguk, 2018).

Bila masa lalu seorang gembala itu buruk, dapat menyebabkan penolakan jemaat pada diri dan pelayanannya. Sebagai contoh, walau Yesus tidak memiliki track record yang buruk tentang masa lalunya, namun ketika Ia berada di Nazaret di kampung halamannya, mereka menolak Dia hanya karena masa lalu Yesus seorang tukang kayu. Bila gembala sidang mempunyai track record hidup di masa lalu buruk, itu dapat mempengaruhi pandangan jemaat atas dirinya. Karena itulah Alkitab menulis Demikian juga orang-orang muda; nasihatilah mereka supaya mereka menguasai diri dalam segala hal, dan jadikanlah dirimu sendiri suatu teladan dalam berbuat baik. Hendaklah engkau jujur dan bersungguh-sungguh dalam 
pengajaranmu, sehat dan tidak bercela dalam pemberitaanmu sehingga lawan menjadi malu, karena tidak ada hal-hal buruk yang dapat mereka sebarkan tentang kita (Ti. 2:6-8). Arifianto (2020a) menyatakan kehidupan orang Kristen itu identik dengan perubahan hidup serta memiliki pertumbuhan kerohanian yang terus-menerus setiap hari dikerjakan. Tanpa perubahan hidup maka kekristenan hanya sebuah retorika. Dengan track record yang baik oleh kehidupan gembala tentunya menambah "kekaguman" jemaat pada diri gembala sehingga ia menjadi role model oleh semua golongan. Jika Allah sudah memberikan mandat panggilan gembala sidang kepada seseorang dalam pelayanan, maka ia harus bertekun dalam penggembalaan agar berumbuh dan berkembang. Tidak hanya bertumbuh, gembala sidang juga dituntut agar cara hidupnya menjadi teladan baik bagi lingkungan maupun bagi jemaat yang digembalakannya. (Simon, 2020a)

\section{Mampu Menjadi Memimpin Rumah Tangga}

Gembala sidang merupakan suami bagi istri dan ayah bagi anak-anaknya sekaligus ia menjadi pemimpin bagi anggota keluarganya. Gembala sidang yang berkompetensi tidak hanya dilihat semata-mata ia memiliki kapabilitas secara intelektual, memiliki kualitas rohani yang baik, serta kharismatik dalam pandangan jemaat. Akan tetapi, gembala sidang yang berkompetensi itu juga dilihat ketika ia mampu menjadi leader (pemimpin) bagi anak dan istrinya. Secara faktual, ditemui fakta di lapangan, ada gembala yang mampu memimpin jemaatnya, namun si gembala itu sendiri tidak bisa memimpin anak dan istrinya. Contoh kalau di dalam Alkitab, imam Eli mampu menjadi imam (pemimpin) bagi umat Israel, namun ia sendiri tidak mampu keberadaan anaknya sebagaimana yang ia ajarkan kepada umat Israel. Sebagaimana yang ditulis oleh firman Allah "Sebab kalau orang tidak tahu mengatur rumah tangganya sendiri, bagaimana ia dapat mengatur jemaat Allah? (1 Tim. 3:5 Terjemahan BIMK).

Alkitab menuliskan bagaimana dursilanya perilaku anak imam Eli yaitu Hotni dan Finehas. Tidak adanya rasa hormat mereka kepada imam Israel yang bertugas di Bait Allah, mereka dengan sesukanya mengambil persembahan korban yang dibawa umat Israel ke Bait Allah, serta bersikap arogansi (1 Sam. 2: 11-17). Alkitab Penuntun Berkelimpahanan menjelaskan bahwa para putra Eli menjadi imam yang jahat di rumah Allah. Mereka menggunakan kedudukan mereka sebagai kesempatan untuk memuaskan keserakahan dan kebejakatan seksual mereka (1 Sam. 13:17). Akan tetapi ayah mereka Eli, imam besar, menolak untuk mendisiplinkan mereka atau memecat mereka dari jabatan sebagai imam. (Alkitab Penuntun Hidup Berkelimpahan, 2000) Pendapat senada dikemukakan oleh Soesilo (2014) bahwa Imam Eli tampaknya tidak menerapkan kedisiplinan dalam mendidik anak. Ia hanya menggunakan kasih sayang dan mengabaikan otoritas yang dimilikinya untuk mendisiplikan anak-anaknya. Disaat kejahatan anak-anaknya sudah sangat serius dan menjadi pembicaraan di antara orang Israel, Eli hanya memberikan teguran lunak, tanpa sedikitpun memberikan teguran yang tegas bagi kejahatan anaknya itu. 
Mampu menjadi pemimpin bagi keluarga diartikan dapat membawa anak dan istrinya menjadi orang yang makin bertumbuh dalam kerohanian, dapat mengatur ketertibanan perilaku angota keluarga. Bila gembala sidang dapat mendidik hidup dan perilaku jemaat yang digembalakannya yang mengarah pada kebaikan, maka terlebih ia harus mampu memimpin anggota keluarganya seperti yang diperbuatnya kepada jemaat. Nyatanya yang penulis amati di lapangan, ada sebagian gembala sidang mampu menjadi pemimpin dan mendidik jemaat, namun ia gagal menjadi pemimpin atas keluarganya. Bentuk kegagalan yang dimaksud, anaknya tidak bisa diatur untuk ikut beribadah, tidak terlibat pelayanan, sementara jemaat dapat dituntun untuk beribadah. Gembala dapat mengarahkan jemaat untuk tidak terlibat dalam narkoba dan minum keras, tetapi oknum gembala itu sendiri gagal karena didapati ada keluarganya terjebak pada narkoba dan minuman keras (Budhi Marpaung, 2017). Rumah tangga gembala sidang menjadi role model bagi jemaat adalah apabila keluarganya menjadi percontohan kepada jemaat. Mengapa keluarga gembala dituntut untuk menjadi role model kepada jemaat, karena pendeta adalah orang yang dijadikan panutan bagi jemaat. Perkataan pendeta didengarkan oleh jemaat, dan perilakunya senantiasa menjadi trend setter bagi jemaat. Hal tersebut bukan hanya berlaku bagi pribadi pendeta tersebut seorang, namun juga bagi keluarganya, yaitu istri dan anak-anaknya. Suka atau tidak, istri dan anak-anak pendeta dituntut juga oleh jemaat untuk memiliki perilaku sebagaimana seorang pendeta, meskipun mereka tidak menjadi pendeta. (Soesilo, 2014)

Gembala sidang yang mampu memimpin keluarganya adalah gembala yang menunjukkan ke-wibawaan-nya serta menunjukkan ia dihormati oleh anak dan istrinya. Dengan mampu memimpin keberadaan keluarganya, ini meletakkan dasar kebenaran firman Allah bahwa seorang pria menjadi kepala atau pemimpin bagi keluarganya. Rumah tangga yang menjadi percontohan bagi jemaat apabila kepemimpinan si gembala kepada keluarganya, dapat membawa seluruh anggota keluarga pada kebaikan dan kebenaran. Karena dengan memimpin keluarga yang berhasil, merupakan miniatur untuk mampu memimpin seluruh jemaat. Riggs mengemukakan seseorang sama sekali tidak dapat mengajar dan memimpin orang lain kalau ia sendiri belum sanggup menjadi teladan. Tetapi biarlah orang itu menyadari bahwa kedudukannya sebagai seorang pemimpin meliputi kewajiban untuk lebih matang, lebih rohani, lebih setia, lebih bertekun di dalam doa, dan lebih saleh dari pada anggotanya. Biarlah setiap gembala memperhatikan bahwa dia harus menjadi teladan yang baik bagi kawanan dombanya dalam semua hal (Riggs, 1996). Dengan mampu memimpin seluruh anggota keluarganya, maka gembala tersebut juga akan mampu memimpin seluruh jemaat, karena ia memberi contoh melalui dirinya dan melalui keberadaan anggota keluarganya.

\section{Gaya Hidup Istri Berpadanan Dengan Alkitab}

Keberhasilan gembala sidang dalam pelayanan turut dipengaruhi oleh peran istrinya sebagai ibu gembala atas jemaat yang dilayaninya. Istri gembala dapat diibaratkan bagian dari penyanggah kehidupan suami untuk tetap ia survive dalam pelayanan. Pentingnya peran istri 
gembala dalam pelayanan, mau tau mau sisi kehidupannya akan disorot dan diperhatikan oleh seluruh jemaat. Rumah tangga gembala sidang menjadi role model bagi jemaat turut didukung oleh kehidupan istri gembala tersebut. Karena istri gembala berperan dalam pengembangan pelayanan, maka dirinya pun dituntut untuk cakap dalam segala hal. Istri yang baik adalah kebanggaan dan kebahagiaan suaminya, istri yang membuat suaminya malu adalah bagaikan penyakit tulang. Istri yang cakap adalah istri yang bisa memenuhi panggilan kodrat kewanitaannya, yaitu dalam hal mengurus rumah, memasak, membimbing dan mendidik anakanaknya serta membantu suaminya serta istri yang cakap mampu untuk mengerjakan pekerjaannya. (Siagian, 2019)

Gembala merupakan sentral utama yang disorot dan dinilai oleh jemaat, setelah itu baru istri. Karena istri bagian dari penilain jemaat, maka ia perlu secara bijak dan berhati-hati agar jangan sampai menjadi "batu sandungan" dalam pelayanan. Karena faktanya, ditemukakan adanya istri-istri gembala yang tidak menjadi role model atau percontohan untuk diteladani oleh jemaat. Contoh ketidak-teladanan istri gembala kepada jemaat dari perkataanya, sikapnya terlebih gaya hidupnya. Berdasarkan wawancara dengan LAS, ada istri gembala yang tidak bisa menempatkan diri ketika ia berbicara. Ia sering berkunjung ke rumah jemaat dan meminta secara bebas apa yang diinginkan. Oknum istri gembala itu juga suka meminjam hutang kepada orang, dan hidup pamer

Gaya hidup istri gembala sidang yang paling sering dinilai atau diperhatikan oleh jemaat. Gaya hidup ini meliputi apa yang dipakainya, aksesoris, serta barang-barang material. Sering sekali istri-istri pengen memiliki apa yang dimiliki oleh tetangganya. Dengan demikian timbullah kerinduan untuk mengkredit dan ironisnya sampai timbul pencurian. Jangan sampai istri mamaksakan kepada suaminya untuk memiliki kemewahan apabila belum ada uang suaminya atau memiliki rumah mewah. Bisa saja akan membuat suaminya melakukan hal-hal yang kotor seperti korupsi agar kebutuhan istrinya terpenuhi (Siagian, 2019). Tidak bisa dipungkiri, ada sebagian istri gembala tidak menjadi role model bagi jemaat, dikarenakan gaya hidup yang ditampilkan di hadapan jemaat sering menjadi perbincangan. Sebagai contoh, kerap ia mempublish hal-hal material di media sosial seperti hang-out di mana ia berada, mempublish makan di restoran termasuk barang-barang yang dipunyai. Dalam kehidupan nyata, pendeta dan keluarganya juga haruslah bersikap penuh bijaksana ketika menampilkan gaya hidup di hadapan jemaat. Jadilah teladan contoh bagi jemaat dalam menampilkan cara hidup yang sederhana tanpa bersikap pamer sekalipun mampu secara ekonomi. Sebab, ekonomi jemaat amatlah beragam, ada yang kaya, sedang, maupun miskin. Dari keragaman ekonomi jemaat itu, maka pendeta dan keluarganya harus menjadi contoh dalam menampilkan bagaimana cara hidup yang sesuai dengan Alkitab. (Simon, 2019)

Gaya hidup istri gembala sidang yang menjadi role model bagi jemaat adalah kesesuain berdasarkan firman Allah. Alkitab menulis "Perhiasanmu janganlah secara lahiriah, yaitu dengan mengepang-ngepang rambut, memakai perhiasan emas atau dengan mengenakan pakain yang indah-indah, tetapi perhiasanmu ialah manusia batiniah yang tersembunyi dengan 
perhiasan yang tidak binasa yang berasal dari roh yang lemah lembut dan tentram, yang sangat berharga di hadapan Allah. Sebab demikianlah caranya perempuan-perempuan kudus dahulu berdandan, yaitu perempuan-perempuan yang menaruh pengharapannya kepada kepada Allah; mereka tunduk kepada suaminya." (1 Ptr. 3:3-5). Dari urain ayat ini, firman Tuhan menekankan bahwa para istri perhiasan utama dalam dirinya bukan hal lahiriah, namun batiniah. Asni mengemukakan wanita yang menghargai karya Allah dalam dirinya akan berusaha untuk menjaga penampilan baik dari dalam maupun luar. Karena ia menyadari bahwa pribadinya bukan milik sendiri tetapi milik Tuhan. Dengan beragamnya model berpakain di masa kini terkadang anak-anak Tuhan terutama kaum perempuan tidak menyadari kalau pakaian yang dikenakan tidak sesuai dengan etika barpakaian, sehingga pribadi anak-anak Tuhan tidak menjadi berkat baik di lingkungan gereja maupun diluar gereja (Duha, 2020). Istri gembala yang menjadi role model bagi rumah tangga jemaat adalah dia yang bijak dengan memprioritaskan inner beuty dari dalam, bukan pada aksseoris yang menempel di badannya dan memprioritaskan gayanya diteladani oleh jemaat yang berdasarkan prinsip utama dalam firman Tuhan. Agar suatu keluarga dapat dikatakan keluarga yang sehat dan bahagia maka harus memiliki beberapa kriteria yang sangat penting bagi perkembangan anak yaitu kehidupan beragama dalam suatu keluarga, mempunyai waktu untuk bersama, mempunyai pola konsumsi yang baik bagi sesama anggota (Aqsho, 2017).

\section{Hubungan Seksualitas Yang Harmonis}

Pengadilan Agama Kabupaten Pati mengemukakan jumlah perceraian di Pati pada tahun 2019, sebanyak dua ribu enam ratus sembilan puluh satu kasus. Penyebab tingginya angka perceraian ini diakibatkan karena perselingkuhan. Penyebab dari perselingkuhan itu adalah tidak harmonisnya hubungan seksualitas suami istri, sehingga menyebabkan salah satu pasangan berselingkuh. Menurut Hurlock suami istri yang harmonis adalah suami istri yang memperoleh kebahagiaan bersama dan membuahkan keputusan yang diperoleh dari peran yang mereka mainkan bersama, mempunyai cinta yang matang dan mantap satu sama lainnya, dan dapat melakukan penyesuaian seksual dengan baik, serta dapat menerima peran sebagai orang tua (Hurlock, 1980). Dosa jatuh dalam perzinahan bukanhal yang asing dalam lingkup pendeta, karena faktanya dosa ini yang sering menyeret para gembala sidang dalam lingkaran perselingkuhan. Penyebab terperosoknya sebagian para kaum rohaniawan ke dalam pusaran perzinahan adalah hubungan seksualitas mereka yang tidak harmonis. Indikator ketidakharmonisan hubungan seksualitas antara istri dan suami adalah, pihak istri melupakan kebutuhan biologis suaminya, sementara suami sering menyibukkan diri dalam urusan kepelayanan pastoralnya.

Umumnya individu pendeta yang terperosok dalam perzinahan, karena kebutuhan biologis (seksualitasnya) tidak didapatkan dari sang istri. Kurangnya pemenuhan kebutuhan biologis oleh salah satu pasangan, menyebabkan terjadinya perzinahan di antara suami atau istri. Selain itu bila hubungan seksualitas suami istri tidak berjalan normal sebagaimana 
mestinya, maka itu dapat mempengaruhi keharmonisan dalam rumah tangga. Nanci dkk mengemukakan dalam kehidupan nyata, tidak semua keluarga dapat tercipta secara harmonis seperti yang dibayangkan banyak orang. Banyak keluarga yang tidak harmonis yang terlihat dari sering terjadinya pertengkaran perselisihan, kekerasan seksual bahkan kekerasan antara anggota keluarga yang satu dengan yang lain (Nancy et al., 2014) Alkitab telah memberikan panduan bagi orang percaya bagaimana supaya terciptanya keharmonisan hubungan seksualitas antara suami dan istri. Adapun panduan Alkitab itu dituliskan oleh rasul Paulus agar "Hendaklah suami memenuhi kewajibannya terhadap isterinya, demikian pula isteri terhadap suaminya. Isteri tidak berkuasa atas tubuhnya sendiri, tetapi suaminya, demikian pula suami tidak berkuasa atas tubuhnya sendiri, tetapi isterinya." (1 Kor. 7:3-4). Dari ungkapan itu dapat dimaknai jangan sampai pemenuhuan kebutuhan (biologis) seksualitas suami istri terhalang oleh salah satu pasangannya. Gulo (2018) mengemukakan Paulus memberikan nasehat hendaklah setiap laki-laki berhubungan seks dengan istrinya, dan hendaklah setiap perempuan berhubungan seks dengan suaminya sendiri. Karena setiap orang yang sudah menikah harus tetap merawat hubungan seksualitasnya dengan istrinya sendiri. Jika melupakan hal ini, maka bahaya percabulan siap menghadang, karena jika dilihat dari potensi kejatuhan amat rentan terjadi perzinahan.

Rumah tangga gembala sidang menjadi role model bagi jemaat bila mereka harmonis secara seksualitas. Tujuannya adalah agar dapat memberikan pembelajaran secara kerohanian apabila ada jemaat-jemaat yang mengalami ketidak-harmonisan rumah tangganya hanya karena permasalahan seksualitas. Upaya yang dapat dilakukan gembala sidang bagi keharmonisan hubungan seksualitasnya dengan pasangannya dimulai dari tidak melupakan pemenuhan kebutuhan biologis. Istri bersama suami merawat diri agar hasrat seksual tidak memudar di antara salah satu pasangan walau usia bertambah. Merawat keharmonisan hubungan seksualitas suami istri sekaligus tidak bersikap munafik di hadapan jemaat. Nyatanya ada sebagian kaum rohaniawan secara seksualitas ia tidak harmonis dengan pasangannya, akan tetapi mereka menutupi di hadapan jemaat, dengan bersikap seolah baik padahal tidak. Seksualitas dalam pernikahan sangat penting karena seksualitas sarana untuk menyatakan kasih. Namun dalam seksualitas juga harus memperhatikan beberapa hal, yaitu kasih Allah menjadi dasar dalam pernikahan, sehingga seksualitas dalam pernikahan juga sebagai perwujudan dari pasangan yang telah dikasihi Allah (Gulo, 2018).

\section{Kesimpulan}

Gembala sidang merupakan jawatan yang diberikan Allah secara khusus kepada seseorang dengan tujuan mengemban amanat Allah untuk menggembalakan jemaat-Nya serta mendidik mereka hidup dalam kebenaran. Dengan Allah memanggil seseorang untuk menjadi gembala, maka hidup dan rumah tangganya harus menjadi role model atau percontohan bagi jemaat. Kehidupan dan rumah tangganya menjadi role model buat jemaat dimulai dari pernikahan mereka haruslah benar, memiliki track record hidup yang baik, ia mampu 
memimpin seluruh anggota keluarganya, dan gaya hidup istrinya tidak menjadi batu sandungan bagi jemaat serta keharmonisan secara seksualitas terjalin erat mereka bina. Oleh sebab itu hendaknya gembala sidang mawas diri agar ia tidak terjatuh pada kesalahan yang dapat menyebabkan hidup dan rumah tangganya menerima stigma negatif. Karena firman Tuhan menyatakan "agar mengawasi diri sendiri dan mengawasi ajaran. Sebab dengan berbuat demikian, engkau akan menyelamatkan dirimu dan semua orang yang mendengar engkau" (1. Tim. 4:16).

\section{Daftar Rujukan}

Alkitab Penuntun Hidup Berkelimpahan. (2000). Gandum Mas.

Aqsho, M. (2017). Keharmonisan Dalam Keluarga Dan Pengaruhnya Terhadap Pengamalan Agama. Almufida, 2(1).

Ariefana, P. (2020). Babak Baru Skandal Pendeta Cabul Surabaya, 17 Tahun Perkosa Anak di Gereja. Arkadia Digital Media.

Arifianto, Y. A. (2020a). Kajian Biblikal tentang Manusia Rohani dan Manusia Duniawi. Jurnal Teruna Bhakti, 3(1).

Arifianto, Y. A. (2020b). Studi Deskriptif 1 Timotius 4:1-16 tentang Pelayan Kristus yang Baik. Jurnal Teologi Rahmat, 6(1).

Borrong, R. P. (2015). Signifikansi Kode Etik Pendeta. GEMA TEOLOGI, 39(1).

Crider, S. M., \& Donald. (2002). Gembala Sidang Dan Pelayanannya. Kalam Hidup.

Duha, A. D. (2020). Etika Berpakaian bagi Kaum Perempuan Dalam I Timotius 2:9-10 dan Aplikasinya Masa Kini. Teologi Berita Hidup, 2(2).

Gulo, M. (2018). Seksualitas Dalam Pernikahan Menurut 1 Korintus 7:1-5. Manna Rafflesia, $4(2)$.

Hurlock, E. B. (1980). Psikologi Perkembangan Suatu Pendekatan Sepanjang Rentang Kehidupan. Erlangga.

Kosta, Y. (2011). Peranan Gembala Sebagai Pemimpin Dalam Perspektif I Petrus 5:1-4 dan Relevansinya Pada Masa Kini. Jaffray, 9(2).

Marpaung, B. (2017). Daniel Waganiaanak Pendeta Yang Terikat Dan Jadi Bandar Narkoba. Jawaban.Com.

Mulyana, D. (2002). No Metode Penelitian. Rosdakarya.

Nancy, M. N., Wismanto, Y. B., \& Hastuti, L. W. (2014). Hubungan Nilai Dalam Perkawinan dan Pemaafan Dengan Keharmonisan Keluarga. Psikodimensia, 13(1). 
Pardede, Z. (2019). Rancang Bangun Teologi "Kekudusan” Tentang Hamba Tuhan Sebagai Pemimpin Kristen Menurut Kitab Yosua. Kharismta Jurnal Teologi Pantekosta, 2(1).

Rajagukguk, J. (2018). Kredibilitas Pribadi Gembala Dalam Pertumbuhan Gereja. Diegesis, $3(2)$.

Riggs, R. M. (1996). Gembala Sidang Yang Berhasil. Gandum Mas.

Sabdono, E. (2018). Perceraian. Rehobot Literature.

Siagian, F. (2019). Figur Istri Yang Bijak Dalam Membina Rumah Tangga Kristen Bahagia Menurut Amsal 31:10-30. Syntax Literate: Jurnal Ilmiah Indonesia, 4(12).

Sihombing, B. (2014). Kepribadian dan kehidupan hamba Tuhan. Jurnal Teologi Agama Kristen, 2(1), 1-13.

Simon. (2019). Fenomena Social Climber Ditinjau Dari Perspektif Etika Kristen. FIDEI: Jurnal Teologi Sistematika Dan Praktika, 2(2).

Simon. (2020a). Peran Roh Kudus Bagi Hamba Tuhan Dalam Merintis Gereja. LOGIA: Jurnal Teologi Pentakosta, 1(2).

Simon. (2020b). Perspektif Alkitab Terhadap Pernikahan Semarga. Jurnal Abdiel: Khazanah Pemikiran Teologi, Pendidikan Agama Kristen Dan Musik Gereja, 4(2).

Soesilo, Y. (2014). Keluarga Eli Dalam 1 Samuel 2:11-36: Suatu Evaluasi Pendidikan Kristen Dalam Keluarga Hamba Tuhan. Antusias, 3(5).

Stott, J. (2015). Isu-Isu Global Edisi Revisi. Yayasan Komunikasi Bina Kasih.

Sugiyono. (2014). Statistika untuk Penelitian (Cetakan ke). ALFABETA.

Sumiwi, A. R. E. (4 C.E.). Gembala Sidang yang Baik Menurut Yohanes 10:1-18. HARVESTER: Jurnal Teologi, 2.

Tanusaputra, D. (2005). Teologi Pernikahan Dan Keluarga. Veritas : Jurnal Teologi Dan Pelayanan, 6(1).

Telaumbanua, A. (2019). Peran Gembala Sidang Sebagai Pendidik Dalam Pertumbuhan Rohani Jemaat. FIDEI: Jurnal Teologi Sistematika Dan Praktika, 2(2), 362-387. https://doi.org/10.34081/fidei.v2i2.45

Wahyudiyanta, I. (2016). Perintahkan Jemaatnya Bercerai, Persekutuan Doa ini Dilaporkan Sesat. DetikNews.

Willyam Barcley. (2000). Pemahaman Alkitab Setiap Hari. BPK Gunung Mulia.

Wongso, P. (1983). Theologia Penggembalaan. SAAT. 
Zed, M. (2008). Metode Penlitian Kepustakaan. Yayasan Obor Indonesia. 